\title{
Flemingia macrophylla in goat feeding
}

\section{Isabel das Neves Oiticica', Carlos Elysio Moreira da Fonseca ${ }^{2}$, Vinícius Carneiro de Souza ${ }^{3}$, Aline Barros da Silva ${ }^{1}$, Fernando César Ferraz Lopes ${ }^{4}$, Mirton José Frota Morenz ${ }^{4}$}

\footnotetext{
${ }^{1}$ Universidade Federal Rural do Rio de Janeiro, Programa de Pós-graduação em Zootecnia, Seropédica, RJ, Brasil.

2 Universidade Federal Rural do Rio de Janeiro, Departamento de Produção Animal, Seropédica, RJ, Brasil.

${ }^{3}$ Universidade Estadual Paulista, Programa de Pós-graduação em Zootecnia, Jaboticabal, SP, Brasil.

${ }^{4}$ Embrapa Gado de Leite, Juiz de Fora, MG, Brasil.
}

\begin{abstract}
The objective of this work was to evaluate the inclusion of Fabaceae Flemingia macrophylla (Willd.) Kuntze ex Merr. in the diet of lactating dairy goats arranged in a $5 \times 5$ Latin square. The diets were composed of $40 \%$ of concentrate and $60 \%$ of roughage, and the dietary treatments were defined by the level of Flemingia hay inclusion $(0 \%, 8 \%$, $16 \%, 24 \%$, and $32 \%$ in the diet dry matter) replacing Cynodon dactylon cv. Tifton 85 hay. The diets were isonitrogenous, with $14 \%$ crude protein. Feed intake, nutrient digestibility, feeding behavior, and ruminal $\mathrm{pH}$ and ammonia nitrogen were evaluated. There was no difference in dry matter intake with the inclusion of Flemingia hay in the diet. The digestibility of dry matter, organic matter, crude protein, neutral detergent fiber, and total carbohydrates decreased with the inclusion of Flemingia in the diet. The diet did not change rumen ammonia nitrogen concentration or ruminal $\mathrm{pH}$. There were no differences in the feeding behavior or feed and rumination efficiencies. Flemingia macrophylla can be used up to the level of $32 \%$ in the dry matter in diets for lactating goats.
\end{abstract}

Key Words: digestibility, feeding behavior, leguminosae, ruminal $\mathrm{pH}$, tropical forage

\section{Introduction}

The seasonality of forage production leads to the use of alternative foods as an option in animal feeding, especially in the dry season, when the pastures, mostly formed by grasses, are scarce and have low nutritional value. Thus, forage legumes have advantages in terms of nutrition, because they have a high protein content, good digestibility, and low decline in nutritional value with advancing phenological stages. Legumes are an important reserve of green food for the dry season and transfer atmospheric nitrogen into the soil through biological fixation (Ben Salem et al., 2005).

Flemingia macrophylla (Willd.) Kuntze ex Merr. is a legume that is adapted to acid soils of low fertility, sandy or clayey, and is drought-tolerant (Salmi et al., 2013). Legumes, such as Flemingia, produce secondary metabolites such as tannins, which can be hydrolyzed or condensed.

Condensed tannins are the most common secondary compound in legumes (Min et al., 2003). They may negatively influence feed intake by the animals by

Received January 6, 2015 and accepted June 25, 2015.

Corresponding author: isabeloiticica@bol.com.br

http://dx.doi.org/10.1590/S1806-92902015000900005

Copyright (C) 2015 Sociedade Brasileira de Zootecnia. This is an Open Access article distributed under the terms of the Creative Commons Attribution License (http://creativecommons.org/licenses/by/4.0/), which permits unrestricted use, distribution, and reproduction in any medium, provided the original work is properly cited. two factors: one is the astringency, which reduces the acceptability of fodder by animals (Reed, 1995), reducing feed intake or the number of visits to the trough (McLeod, 1974; Jansman, 1993; Reed, 1995). The other factor is the effect of tannin on the nutrient digestibility by forming complexes with proteins and carbohydrates, reducing the ruminal degradation of these nutrients, or complexation with microbial enzymes, decreasing its activity and consequently the digestibility of the feed (Makkar et al., 1988). Additionally, tannins can reduce enteric methane production, so they are important for mitigating greenhouse gas emission by ruminants (Makkar, 2003).

Lignin, another plant compound, contributes to the structural integrity, resistance to degradation, and water impermeability of plants (Hatfield et al., 1999). According to Van Soest (1994), lignin is present in greater amounts in legumes than in grasses and its main effect on animal nutrition is the reduction of digestibility.

This study was conducted to evaluate the feeding behavior, feed intake, ruminal $\mathrm{pH}$ and ammonia nitrogen, and digestibility of the nutrients in lactating goats fed increasing levels of Flemingia macrophylla (Willd.) Kuntze ex Merr.

\section{Material and Methods}

This work was conducted in accordance with the ethical standards of the institution. 
The experiment was carried out in 2011 from August to December in Seropédica - RJ, Brazil. The Flemingia macrophylla (Willd.) Kuntze ex Merr. plants were cut to $1 \mathrm{~m}$ height and the thick stems were separated from the leaves and thin stems. This fraction and the grass Cynodon dactylon cv. Tifton 85 were sun-dried.

Five crossbred dairy goats (Saanen $\times$ Boer) with an initial weight of $46.5 \mathrm{~kg}$ and $1.5 \mathrm{~kg}$ milk/day, in midlactation, were arranged in a $5 \times 5$ Latin square. The animals were kept in individual pens with apparatus for total collection of feces. Each experimental period lasted 11 days: seven for adaptation to the diet and four for the collection of samples and data.

Diets were isonitrogenous, with $14 \%$ crude protein (CP), and were composed of $40 \%$ concentrate and $60 \%$ hay (dry matter basis) (Table 1). The treatments were the levels of inclusion of legume hay (Flemingia macrophylla) replacing grass hay (Cynodon dactylon cv. Tifton 85) in the forage part of the diet.

The treatments were the following: Control - $60 \%$ Cynodon dactylon hay $+40 \%$ concentrate; 8\% Flemingia macrophylla hay $+52 \%$ C. dactylon hay $+40 \%$ concentrate; $16 \%$ F. macrophylla hay $+44 \%$ C. dactylon hay $+40 \%$ concentrate; $24 \%$ F. macrophylla hay $+36 \%$ C. dactylon hay $+40 \%$ concentrate; and 32\% F. macrophylla hay + $28 \%$ C. dactylon hay $+40 \%$ concentrate.

The diet was formulated according to the nutritional requirements of goats (NRC, 2007) (Table 2). The goats received feed twice daily to allow for $15 \%$ of leftovers in relation to the total offered, thus ensuring animal selectivity and the voluntary feed intake. The animals received water and mineral mixture for goat ad libitum.

The samples of feed, orts, and feces were oven-dried at $55^{\circ} \mathrm{C}$ and finely ground $(1 \mathrm{~mm})$. These samples were analyzed for dry matter (DM), crude protein (CP), ether extract (EE), and total ash using AOAC methods 934.01, 976.05, 954.02, and 942.05, respectively (AOAC, 1990).

The concentrations of neutral detergent fiber (NDFom) and acid detergent fiber (ADF) were determined using the method proposed by VanSoest et al. (1991). NDF analysis was not performed in the presence of $\alpha$-amylase

Table 1 - Chemical composition of the diet ingredients

\begin{tabular}{lcccc}
\hline Component & Flemingia & Tifton 85 & $\begin{array}{c}\text { Corn } \\
\text { meal }\end{array}$ & $\begin{array}{c}\text { Soybean } \\
\text { meal }\end{array}$ \\
\hline Dry matter (\%) & 86.76 & 83.76 & 87.16 & 87.23 \\
Crude protein (\%DM) & 16.32 & 14.53 & 9.15 & 52.37 \\
Ether extract (\%DM) & 3.40 & 2.06 & 3.97 & 1.62 \\
Neutral detergent fiber (\%DM) & 61.30 & 68.93 & 15.28 & 14.06 \\
Acid detergent fiber (\%DM) & 47.59 & 34.45 & 3.78 & 9.88 \\
Mineral matter (\%DM) & 6.08 & 6.44 & 1.73 & 6.76 \\
\hline
\end{tabular}

and sodium sulfite $\left(\mathrm{Na}_{2} \mathrm{SO}_{3}\right)$. In addition, the residue from the NDF analyses was filtered in Goochs crucibles and the concentration of ash in the residual material was determined by combustion at $600{ }^{\circ} \mathrm{C}$ for $3 \mathrm{~h}$ (AOAC, 1990; method 942.05).

The carbohydrate fractions were obtained using the methodology described by Sniffen et al. (1992) (Table 3).

Saponins were identified by dissolving the extract in water with constant stirring. The formation and persistence (for $15 \mathrm{~min}$ ) of foam indicates the presence of saponins in plant extracts (Dewick, 2002).

Samples of rumen contents were collected by an esophageal tube and a vacuum pump four hours after meal on the 11th day of each experimental period for determination of $\mathrm{pH}$ and $\mathrm{N}-\mathrm{NH}_{3}$ concentration in the rumen fluid. The $\mathrm{pH}$ was measured immediately after collection. For the quantification of the ammonia concentration, $50 \mathrm{~mL}$ of rumen fluid were filtered and $1 \mathrm{~mL}$ of sulfuric acid - $\mathrm{H}_{2} \mathrm{SO}_{4}$ (1:1) was added to the filtrate and subsequently distilled over potassium hydroxide - KOH 2N (Vieira, 1980).

The observation of the feeding behavior began on the 5 th day of each experimental period and lasted $24 \mathrm{~h}$. The interval between observations was $20 \mathrm{~min}$, as validated

Table 2 - Ingredients and chemical composition of the diets according to the level of the Flemingia hay

\begin{tabular}{lccccc}
\hline & \multicolumn{5}{c}{ Flemingia level } \\
\cline { 2 - 6 } Ingredient & $0 \%$ & $8 \%$ & $16 \%$ & $24 \%$ & $32 \%$ \\
\hline Cynodon dactylon hay (\%) & 60 & 52 & 44 & 36 & 28 \\
Flemingia macrophylla hay (\%) & 0 & 8 & 16 & 24 & 32 \\
Corn meal (\%) & 36.2 & 36.6 & 36.8 & 37.2 & 37.5 \\
Soybean meal (\%) & 3.8 & 3.4 & 3.2 & 2.8 & 2.5 \\
Nutrient & & & & & \\
Dry matter (\%) & 83.0 & 83.7 & 84.0 & 84.7 & 85.3 \\
Organic matter (\%DM) & 95.5 & 95.5 & 95.6 & 95.6 & 95.7 \\
Crude protein (\%DM) & 14.0 & 14.0 & 14.0 & 14.0 & 14.0 \\
Ether extract (\%DM) & 2.7 & 2.9 & 3.0 & 3.1 & 3.2 \\
Neutral detergent fiber (\%DM) & 47.4 & 46.8 & 46.2 & 45.6 & 45.0 \\
Acid detergent fiber (\%DM) & 22.4 & 23.4 & 24.5 & 25.5 & 26.6 \\
Lignin (\%DM) & 3.5 & 4.8 & 6.1 & 7.6 & 8.8 \\
Total carbohydrates (\%DM) & 78.6 & 78.5 & 78.4 & 78.3 & 78.2 \\
Non-fiber carbohydrates (\%DM) & 33.0 & 33.6 & 34.1 & 34.7 & 35.2 \\
Mineral matter (\%DM) & 4.45 & 4.45 & 4.41 & 4.36 & 4.30 \\
\hline
\end{tabular}

Table 3 - Fractionation of carbohydrates and lignin content in Flemingia macrophylla and Tifton 85 hays

\begin{tabular}{lcc}
\hline Component & Tifton 85 & Flemingia macrophylla \\
\hline Total carbohydrates (\%DM) & 76.9 & 74.2 \\
Fraction "C" (\%DM) & 12.1 & 49.6 \\
Fraction "B2" (\%DM) & 56.8 & 11.7 \\
Non-fiber carbohydrates (\%DM) & 8.0 & 12.9 \\
Lignin (\%DM) & 5.06 & 20.66 \\
\hline
\end{tabular}


by Carvalho et al. (2007), in which the feeding (including consumption of feed, water, and mineral salts) idling, and rumination times were recorded. During the night time observation the shed was lit minimally to facilitate the observation, but without interfering with the animals' natural behavior. Trained observers took turns of two shifts. Based on the ingestive behavior data, it was possible evaluate feed efficiency (FE), rumination efficiency (RUE), and total time spent chewing (TSC) according to the formulas of Bürger et al. (2000): $\mathrm{FE}_{\mathrm{DM}}=\mathrm{DMI}$ (g/day)/TSF (h/day); $\mathrm{FE}_{\mathrm{NDF}}=\mathrm{NDF}(\mathrm{g} /$ day $) / \mathrm{TSF}$ (h/day); $\mathrm{RUE}_{\mathrm{DM}}=\mathrm{DMI}(\mathrm{g} /$ day $) / \mathrm{TSR}$ (h/day); $\operatorname{RUE}_{\mathrm{NDF}}=\mathrm{NDF}$ (g/day)/TSR (h/day); TSC (min/day) = $\mathrm{TSF}+\mathrm{TSR}$, in which: $\mathrm{FE}_{\mathrm{DM}}\left(\mathrm{g} \mathrm{DM}\right.$ consumed/h); $\mathrm{FE}_{\mathrm{NDF}}$ (g NDF consumed/h); RUE ${ }_{D M}$ (g DM ruminated/h); RUE NDF (g NDF ruminated/h), DMI (dry matter intake); TSF (time spent feeding); and TSR (time spent ruminating).

The results were subjected to analysis of variance and regression through the PROC MIXED procedure of SAS (Statistical Analysis System, version 9.0). Effects were considered significant at $\alpha=0.05$.
The following statistical model was used:

$$
\mathrm{Y}_{i j k}=\mu+\mathrm{P}_{i}+\mathrm{A}_{j}+\alpha_{k}+\mathrm{e}_{i j k},
$$

in which $\mathrm{Y}_{\mathrm{ijk}}=$ observation of animal $j$ subjected to treatment $k$ in period $i ; \mu=$ overall mean effect; $\mathrm{P}_{i}=$ effect of period $i ; \mathrm{A}_{j}=$ effect of animal $j ; \alpha_{k}=$ treatment effect $k$; and $\mathrm{e}_{i j k}=$ random error $i j k(i=$ period $(1,2,3,4,5)$, $j=$ animal $(1,2,3,4,5)$, and $k=$ treatment $(0 \%, 8 \%, 16 \%$, $24 \%$, and $32 \%$ of Flemingia replacing Tifton hay)).

Lilliefors and Cochran's and Bartlett's tests were performed to check the normal distribution of the evaluated data.

\section{Results}

Saponin was detected in samples of Flemingia. The test conducted was qualitative, so there was no quantification of saponin content in the legume in question.

There were no differences in feeding behavior, feed and rumination efficiencies, or total chewing time for the animals subjected to different treatments (Table 4).

Table 4 - Means and coefficients of variation (CV) for feeding-behavior activities in different treatments

\begin{tabular}{|c|c|c|c|c|c|c|c|}
\hline \multirow{2}{*}{ Activity } & \multicolumn{5}{|c|}{ Flemingia level } & \multirow{2}{*}{ Mean } & \multirow{2}{*}{$\mathrm{CV}$} \\
\hline & $0 \%$ & $8 \%$ & $16 \%$ & $24 \%$ & $32 \%$ & & \\
\hline Rumination (min) & 260 & 288 & 308 & 296 & 296 & $\hat{Y}=289.6$ & 23.09 \\
\hline Idling (min) & 792 & 748 & 748 & 728 & 776 & $\hat{\mathrm{Y}}=758.4$ & 11.48 \\
\hline Feeding (min) & 388 & 404 & 384 & 416 & 368 & $\hat{\mathrm{Y}}=392.0$ & 19.81 \\
\hline $\mathrm{FE}(\mathrm{g} \mathrm{DM} / \mathrm{h})$ & 255 & 268 & 284 & 275 & 305 & $\hat{\mathrm{Y}}=277.4$ & 23.69 \\
\hline $\mathrm{FE}(\mathrm{g} \mathrm{NDF} / \mathrm{h})$ & 0.09 & 0.10 & 0.11 & 0.11 & 0.12 & $\hat{\mathrm{Y}}=0.11$ & 27.99 \\
\hline RUE (g DM/h) & 404 & 364 & 376 & 387 & 394 & $\hat{\mathrm{Y}}=385.0$ & 27.71 \\
\hline RUE (g NFD/h) & 0.15 & 0.14 & 0.15 & 0.15 & 0.15 & $\hat{\mathrm{Y}}=0.15$ & 28.50 \\
\hline Total chewing time (h) & 10.8 & 11.53 & 11.53 & 11.87 & 11.07 & $\hat{\mathrm{Y}}=11.4$ & 16.33 \\
\hline
\end{tabular}

FE - feed efficiency; RUE - rumination efficiency; DM - dry matter; NDF - neutral detergent fiber.

Table 5 - Means, coefficients of variation $(\mathrm{CV})$ and determination $\left(\mathrm{r}^{2}\right)$, and regression equations for the intake of nutrients in the different treatments

\begin{tabular}{|c|c|c|c|c|c|c|c|c|}
\hline \multirow{2}{*}{ Item } & \multicolumn{5}{|c|}{ Flemingia level } & \multirow{2}{*}{$\mathrm{CV}$} & \multirow{2}{*}{$r^{2}$} & \multirow{2}{*}{ Regression } \\
\hline & $0 \%$ & $8 \%$ & $16 \%$ & $24 \%$ & $32 \%$ & & & \\
\hline $\mathrm{DM}^{1}$ & 1.62 & 1.68 & 1.79 & 1.85 & 1.78 & 13.00 & - & $\hat{\mathrm{Y}}=1.74$ \\
\hline $\mathrm{DM}^{2}$ & 3.16 & 3.24 & 3.40 & 3.53 & 3.40 & 11.52 & - & $\hat{\mathrm{Y}}=3.35$ \\
\hline $\mathrm{OM}^{1}$ & 1.56 & 1.61 & 1.72 & 1.77 & 1.71 & 12.88 & - & $\hat{\mathrm{Y}}=1.67$ \\
\hline $\mathrm{CP}^{1}$ & 0.23 & 0.25 & 0.27 & 0.27 & 0.26 & 12.50 & - & $\hat{\mathrm{Y}}=0.26$ \\
\hline $\mathrm{EE}^{1}$ & 0.056 & 0.063 & 0.065 & 0.065 & 0.093 & 16.60 & 0.47 & $\hat{\mathrm{Y}}=0.0533+0.00094 \mathrm{X}$ \\
\hline NDFom $^{1,3}$ & 0.60 & 0.63 & 0.70 & 0.73 & 0.69 & 15.86 & - & $\hat{\mathrm{Y}}=0.67$ \\
\hline NDFom $^{2,3}$ & 1.17 & 1.22 & 1.33 & 1.39 & 1.32 & 14.11 & - & $\hat{\mathrm{Y}}=1.28$ \\
\hline $\mathrm{ADF}^{1}$ & 0.28 & 0.32 & 0.38 & 0.41 & 0.42 & 15.35 & 0.45 & $\hat{\mathrm{Y}}=0.2912+0.00448 \mathrm{X}$ \\
\hline $\operatorname{Lignin}^{1}$ & 0.048 & 0.074 & 0.099 & 0.133 & 0.153 & 16.91 & 0.83 & $\hat{\mathrm{Y}}=0.0474+0.00335 \mathrm{X}$ \\
\hline Hemicellulose $^{1}$ & 0.39 & 0.29 & 0.26 & 0.25 & 0.23 & 47.71 & - & $\hat{\mathrm{Y}}=0.28$ \\
\hline $\mathrm{TC}^{1}$ & 1.27 & 1.31 & 1.39 & 1.44 & 1.39 & 13.27 & - & $\hat{\mathrm{Y}}=1.36$ \\
\hline $\mathrm{NFC}^{1}$ & 0.70 & 0.71 & 0.73 & 0.75 & 0.73 & 13.57 & - & $\hat{\mathrm{Y}}=0.72$ \\
\hline $\mathrm{TDN}^{1}$ & 1.21 & 1.17 & 1.23 & 1.21 & 1.19 & 14.36 & - & $\hat{\mathrm{Y}}=1.201$ \\
\hline
\end{tabular}

DM - dry matter; OM - organic matter; CP - crude protein; EE - ether extract; NDFom - neutral detergent fiber; ADF - acid detergent fiber; TC - total carbohydrates; NFC - non-fiber carbohydrates; TDN - total digestible nutrients.

${ }^{1} \mathrm{~kg} /$ day.

$2 \%$ BW.

${ }^{3}$ Not assayed with heat-stable amylase and expressed exclusive of residual ash. 
The time spent on each feeding behavior is related to the intake and digestibility of the diet. There were no differences in the intakes of dry matter, organic matter, mineral matter, crude protein, or neutral detergent fiber by goats subjected to different treatments. The intake of ether extract, acid detergent fiber, and lignin increased linearly with the dietary inclusion of Flemingia (Table 5).

There were differences $(\mathrm{P}<0.05)$ in the digestibility of dry matter, organic matter, crude protein, ether extract, NDFom, ADF, and total carbohydrate (Table 6).

No differences for the values of ruminal ammonia nitrogen and $\mathrm{pH}$ were found (Table 7) with the dietary inclusion of Flemingia.

\section{Discussion}

Flemingia saponins may have had effects on the the feeding and nutrition of animals. Saponins can inhibit the growth and activity of ruminal microorganisms (Taiz and Zeiger, 2004), decreasing the acetate:propionate ratio (Kamra, 2005). Furthermore, the saponins may bring some nutritional benefits related to the reduction of the protozoa population in the rumen ( $\mathrm{Lu}$ and Jorgensen, 1987).

The presence of tannin in Flemingia macrophylla was confirmed by other authors, who found levels of $2 \%$ and 5\% (Tiemann et al., 2008), and by Fagundes (2012), who observed $10.5 \%$ condensed tannin in F. macrophylla. However, Aviz et al. (2009) described a low content of this compound in Flemingia, which was set at $1.37 \%$. This divergence of values may occur because of the influence of factors such as climate, plant mineral nutrition, growth, and chemical composition (Waterman and Mole, 1994), which directly affect the formation of tannin.

The total carbohydrates from grass and legume were similar, $76 \%$ and $74.2 \%$ respectively; the fraction " $\mathrm{C}$ " content of Flemingia (49.6\%) was higher than that of the grass $(12.1 \%)$. The fraction " $\mathrm{C}$ " is the fiber indigestible fraction (Sniffen et al., 1992), and so the observed fraction " $\mathrm{C}$ " is consistent with the high lignin content in Flemingia, which was greater than $20 \%$, in agreement with reports of a high content of lignin in legumes (Grenet and Besle, 1991; Valente et al., 2011). Furthermore, the methodology used for determining lignin, which was the potassium permanganate, according to Jung (1997) and Goering and Van Soest (1970), overestimates the amount of lignin by the removal of other cell wall components, by interference from other solubilized compounds, and because particles of various sizes are not treated equally. Even with this, the lignin content of Flemingia was high and may have had a great influence on the digestibility of polysaccharides.

The fraction "B2", which is slowly digested, was superior in Tifton $(56.8 \%)$ than in Flemingia (11.7\%). Fagundes (2012) made similar a report, in which he observed $22.6 \%$ fraction "B2" in Flemingia and $51.8 \%$ for Tifton. The levels of non-fiber carbohydrates (NFC) were

Table 6 - Means, coefficients of variation $(\mathrm{CV})$ and determination $\left(\mathrm{r}^{2}\right)$, and regression equations for the digestibility of nutrients in the different treatments

\begin{tabular}{|c|c|c|c|c|c|c|c|c|}
\hline \multirow{2}{*}{ Item } & \multicolumn{5}{|c|}{ Flemingia level } & \multirow{2}{*}{$\mathrm{CV}$} & \multirow{2}{*}{$r^{2}$} & \multirow{2}{*}{ Regression } \\
\hline & $0 \%$ & $8 \%$ & $16 \%$ & $24 \%$ & $32 \%$ & & & \\
\hline $\mathrm{DM}(\mathrm{g} / \mathrm{kg})$ & 718 & 669 & 661 & 628 & 605 & 5.29 & 0.54 & $\hat{\mathrm{Y}}=709-3.3 \mathrm{X}$ \\
\hline $\mathrm{OM}(\mathrm{g} / \mathrm{kg})$ & 737 & 685 & 676 & 644 & 621 & 5.07 & 0.56 & $\hat{\mathrm{Y}}=727-3.4 \mathrm{X}$ \\
\hline $\mathrm{CP}(\mathrm{g} / \mathrm{kg})$ & 683 & 605 & 588 & 527 & 488 & 7.87 & 0.68 & $\hat{Y}=672.2-5.87 X$ \\
\hline $\mathrm{EE}(\mathrm{g} / \mathrm{kg})$ & 752 & 737 & 720 & 727 & 818 & 5.95 & 0.005 & $\hat{\mathrm{Y}}=726.3+1.53 \mathrm{X}$ \\
\hline NDFom $(\mathrm{g} / \mathrm{kg})^{1}$ & 585 & 437 & 465 & 406 & 353 & 14.02 & 0.37 & $\hat{\mathrm{Y}}=548.7-6.209 \mathrm{X}$ \\
\hline $\operatorname{ADF}(\mathrm{g} / \mathrm{kg})$ & 569 & 431 & 436 & 373 & 316 & 20.61 & 0.45 & $\hat{\mathrm{Y}}=537.9-7.06 \mathrm{X}$ \\
\hline Hemicellulose $(\mathrm{g} / \mathrm{kg})$ & 626 & 403 & 595 & 580 & 520 & 41.9 & - & $\hat{\mathrm{Y}}=544.8$ \\
\hline $\mathrm{TC}(\mathrm{g} / \mathrm{kg})$ & 746 & 699 & 693 & 665 & 643 & 5.24 & 0.47 & $\hat{\mathrm{Y}}=737.4-3.00 \mathrm{X}$ \\
\hline $\mathrm{NFC}(\mathrm{g} / \mathrm{kg})$ & 898 & 946 & 923 & 931 & 930 & 4.08 & - & $\hat{\mathrm{Y}}=925.6$ \\
\hline
\end{tabular}

DM - dry matter; OM - organic matter; CP - crude protein; EE - ether extract; NDFom - neutral detergent fiber; ADF - acid detergent fiber; TC - total carbohydrates; NFC - non-fiber carbohydrates.

${ }^{1}$ NDF not assayed with heat-stable amylase and expressed exclusive of residual ash.

Table 7 - Means, coefficients of variation (CV), coefficients of determination $\left(\mathrm{r}^{2}\right)$, and regression equations adjusted to the values of ammonia nitrogen $\left(\mathrm{NH}_{3}-\mathrm{N}\right)$ and ruminal $\mathrm{pH}$ in different treatments

\begin{tabular}{|c|c|c|c|c|c|c|c|}
\hline \multirow{2}{*}{ Item } & \multicolumn{5}{|c|}{ Flemingia level } & \multirow{2}{*}{ Mean } & \multirow{2}{*}{$\mathrm{CV}$} \\
\hline & $0 \%$ & $8 \%$ & $16 \%$ & $24 \%$ & $32 \%$ & & \\
\hline $\mathrm{N}-\mathrm{NH}_{3}(\mathrm{mg} / \mathrm{dL})$ & 19.12 & 18.10 & 16.68 & 14.20 & 11.17 & $\hat{\mathrm{Y}}=15.85$ & 29.765 \\
\hline Ruminal pH & 6.64 & 6.72 & 6.94 & 6.90 & 6.92 & $\hat{\mathrm{Y}}=6.82$ & 0.02 \\
\hline
\end{tabular}


higher in Flemingia (12.9\%) compared with Tifton (8\%), due to the higher content of cellular matter in legumes (Bumbieris Junior et al., 2011). However, Fagundes (2012) found a higher NFC level in Flemingia (54.1\%) than in this study, possibly because only the leaves of the legume were used and not the leaves and stems, as tested in this study. Carvalho et al. (2004) reported that rumination efficiency is an important tool for analyzing low-digestibility foods. The level of dietary Flemingia did not influence the feed and rumination efficiencies expressed in $\mathrm{g} N \mathrm{NF} / \mathrm{h}$, because the intakes of NDF did not differ between the diets.

The animals spent more time idle at night and the longest period of rumination occurred at dawn, which is a common behavior according to Gonçalves et al. (2001). The feeding activity predominated in the morning and afternoon, while during the night and early morning the prevailing behavior was idleness.

The lack of difference between the intakes of diets shows good acceptability of Flemingia by goats, and the presence of lignin, saponin, and tannin did not influence the acceptability by the animals. The TDN intake was similar and was sufficient to meet the animals' requirements (NRC, 2007).

The higher intake of EE is related to the higher content of this component in the diets with more Flemingia and corn, because these ingredients have more EE than Tifton and soybean meal, respectively. The higher intake of ADF in diets with a higher content of Flemingia can be justified by the greater percentage in this legume. Flemingia is also rich in lignin $(20.66 \% \mathrm{DM})$, and so the intake of lignin was higher in diets with higher concentrations of Flemingia replacing Tifton.

The intakes of DM and CP were higher than the $1.6 \mathrm{~kg}$ and $0.14 \mathrm{~kg}$ predicted by AFRC (1993) for animals with $46.5 \mathrm{~kg}$ and $1.5 \mathrm{~kg}$ of milk per day. Diets with Flemingia met the animals' nutritional requirements.

Fagundes (2012) fed goats with Flemingia and obtained results close to the average values found in this study (DMI of $1.77 \mathrm{~kg} /$ day, OMI of $1.71 \mathrm{~kg} /$ day, and CPI of $0.27 \mathrm{~kg} /$ day) and intakes were similar between animals. Mui et al. (2001) fed goats with Flemingia, and when they included the legume, the goats reduced their DMI. Aviz (2007) achieved good values for DMI and CP even with the addition of $100 \%$ Flemingia in the diet.

The CP intake by goats was equivalent in the five treatments, because the diets were isonitrogenous. Thus, for every increase in the level of the legume in the diet, there was a decrease in soybean meal added to the concentrate.
The apparent digestibility of DM, OM, CP, NDFom, $\mathrm{ADF}$, and TC showed a linear decrease with the increasing level of dietary Flemingia. Fagundes (2012) also found decreased digestibility of DM, OM, CP, NDF, and TC with the inclusion of Flemingia in the diet of lactating goats. These results may be due to three reasons, two of them related to the presence of condensed tannins in legumes. One explanation is the formation of complexes between tannins and proteins or carbohydrates in the diet, reducing nutrient availability, and the other is the complexation of tannins with microbial enzymes, reducing their activity and thus the digestibility of the diet. The third possibility is related to the lignin content of Flemingia, which may have been responsible for the greater decline in digestibility.

The ether extract digestibility showed a linear response with increasing dietary levels of Flemingia. This shows that despite a lower digestibility of the other components of the diet, there was an energetic compensation with higher EE digestibility.

The presence of condensed tannins in Flemingia could alter the rumen $\mathrm{pH}$, which did not occur in this study. Another factor that could contribute to increased $\mathrm{pH}$ is the lignin content of Flemingia. Diets with more Flemingia had a higher lignin content and could provide lower production of fatty acids (Gomes et al., 2009), raising the $\mathrm{pH}$. The higher concentrations of Flemingia also could increase the ruminal $\mathrm{pH}$ due to the higher buffering capacity of vegetables compared with grasses (Whittenbury et al., 1967).

According to Satter and Slyter (1974), the minimum value of ammonia nitrogen to maintain normal rumen function is $5 \mathrm{mg} / \mathrm{dL}$. The average ammonia nitrogen found in this study was $15.85 \mathrm{mg} / \mathrm{dL}$ of ruminal fluid, a value within the normal range, and did not vary with the different diets. The presence of ammonia nitrogen in the rumen is essential for microbial growth, providing an adequate fermentation rate (Van Soest, 1994).

\section{Conclusions}

Flemingia macrophylla hay can be used up to the level of $32 \%$ in the dry matter of the diet of lactating goats without impairing nutrient intake.

\section{Acknowledgments}

To Coordenação de Aperfeiçoamento de Pessoal de Nível Superior (CAPES) for granting the scholarship; to Empresa Brasileira de Pesquisa Agropecuária (EMBRAPA) 
Embrapa Dairy Cattle for the help with the laboratory; and to Embrapa Agrobiology for donating the Flemingia for research.

\section{References}

AFRC - Agricultural and Food Research Council. 1993. Energy and protein requirements of ruminants. An advisory manual prepared by the AFRCT Technical Committee on responses to nutrients. CAB International, Wallingford, UK.

AOAC - Association of Official Analytical Chemists. 1990. Official methods of analysis of the Association of Official Analytical Chemists. 15th ed. AOAC International, Arlington, VA.

Aviz, M. A. B.; Lorenzo Júnior, J. B. L.; Camarão, A. P. and Garcia, A. R. 2009. Valor nutritivo da leguminosa Flemingia macrophylla (Willd.) Merrill para suplementação alimentar de ruminantes na amazônia oriental. Amazônia: Ciência \& Desenvolvimento 4:253-272.

Aviz, M. A. B. 2007. Valor nutritivo da leguminosa Flemingia macrophylla (Willd.) Merrill para suplementação alimentar de ruminantes na amazônia oriental. Dissertation (M.Sc.). Universidade Federal do Pará, Belém.

Ben Salem, H.; Saghrouni, L. and Nefzaoui, A. 2005. Attempts to deactivate tannins in fodder shrubs with physical and chemical treatments. Animal Feed Science and Technology 122:109-121.

Bumbieris Junior, B. H. V.; Jobim, D. C.; Emile, J. C.; Rossi, R.; Calixto Jr., M. and Branco, A. F. 2011. Degradabilidade ruminal e fracionamento de carboidratos e proteína em silagens de triticale em cultivo singular ou misturas com aveia e/ou leguminosas. Semina: Ciências Agrárias 32:759-770.

Bürger, P. J.; Pereira, J. C. and Queiroz, A .C. 2000. Comportamento ingestivo em bezerros holandeses alimentados com dietas contendo diferentes níveis de concentrado. Revista Brasileira de Zootecnia 29:236-242.

Carvalho, G. G. P.; Pires, A. J. V.; Silva, F. F.; Veloso, C. M.; Silva, R. R.; Silva, H. G. O.; Bonomo, P. and Mendonça, S. S. 2004. Comportamento ingestivo de cabras leiteiras alimentadas com farelo de cacau e torta de dendê. Pesquisa Agropecuária Brasileira 39:919-925.

Carvalho, G. G. P.; Pires, A. J. V.; Silva, H. G. O.; Veloso, C. M. and Silva, R. R. 2007. Aspectos metodológicos do comportamento ingestivo de cabras lactantes alimentadas com farelo de cacau e torta de dendê. Revista Brasileira de Zootecnia 36:103-110.

Dewick, P. M. 2002. Medicinal natural products: A biosynthetic approach. 2th ed. John Wiley \& Sons LTD, West Sussex.

Fagundes, G. M. 2012. Desempenho produtivo e composição do leite de cabras alimentadas com dietas contendo diferentes níveis de Flemingia macrophylla (Willd.) Merrill com e sem polietilenoglicol. Dissertation (M. Sc.). Universidade Federal Rural do Rio de Janeiro, Seropédica.

Goering, H. K. and Van Soest, P. J. 1970. Forage fiber analysis: apparatus, reagents, procedures and some applications. Agriculture Handbook $\mathrm{N}^{\circ}$ 379. USDA/ARS, Washington, DC.

Gomes, G. M. F.; Vasconcelos, A. M.; Egito, A. S.; Salles, H. O.; Bomfim, M. A. D.; Fonteles N. L. O.; Rogério, M. C. P. and Costa, H. H. A. 2009. Parâmetros ruminais de caprinos e ovinos nativos do nordeste brasileiro alimentados com dietas à base de bagaço de cana-de-açúcar in natura. In: Anais do 11ํㅡㄹ Encontro de iniciação científica; 3 ํㅡㄹ Encontro de Pós-graduação e Pesquisa. Universidade Estadual Vale do Acaraú, Sobral.

Gonçalves, A. L.; Lana, R. P.; Rodrigues, M. T.; Vieira, R. A. M.; Queiroz, A. C. and Henrique, D. S. 2001. Padrão nictemeral do pH ruminal e comportamento alimentar de cabras leiteiras alimentadas com dietas contendo diferentes relações volumoso:concentrado. Revista Brasileira de Zootecnia 30:1886-1892.

Grenet, E. and Besle, J. M. 1991. Microbes and fiber degradation. p.107-129. In: Rumen microbial metabolism and ruminant digestion. Jouany, J. P., ed. INRA Editions, Paris.

Hatfield, R. D.; Ralph, J. and Grabber, J. H. 1999. Cell wall structural foundations: molecular basis for Improving forage digestibility. Crop Science 39:27-37.

Jansman, A. J. M. 1993. Tannins in feedstuffs for simple-stomached animals. Nutrition Research Reviews 6:209-236.

Jung, H. G. 1997 Analysis of forage fiber and cell walls in ruminant nutrition. Journal of Nutrition 127:810-813.

Kamra, D. N. 2005. Rumen microbial ecosystem. Current Science 89:124-134.

Lu, C. D. and Jorgensen, N. A. 1987. Alfalfa saponins affect site and extent of nutrient digestion in ruminants. Journal of Nutrition 117:919-927.

Makkar, H. P. S. 2003. Effect and fate of tannins in ruminant animals, adaptation to tannins, and strategies to overcome detrimental effects of feeding tannin rich feeds. Small Ruminant Research 49:241-256.

Makkar, H. P. S.; Singh, B. e Dawra, R. K. 1988. Effect of tannin-rich leaves of oak (Quercus incana) on various microbial enzyme activities of the bovine rumen. British Journal of Nutrition 60:287-296.

McLeod, M. N. 1974. Plant tannins - their role in forage quality. Nutrition Abstracts and Reviews 44:803-815.

Min, B. R.; Barry, T. N.; Attwood, G. T. and McNabb, W. C. 2003. The effect of condensed tannins on the nutrition and health of ruminants fed fresh temperate forages: a review. Animal Feed Science and Technology 106:3-19.

Mui N.T.; Ledin, I.; Uden, P. e Binh, D.V. 2001. Effect of Replacing a rice bran-soya bean concentrate with Jackfruit (Artocarpus heterophyllus) or Flemingia (Flemingia macrophylla) foliage on the performance of growing goats. Livestock Production Science 72:253-262.

NRC - National Research Council. 2007 - Nutrient requirements of small ruminants: Sheep, goats, cervids, and camelids New Worlds. National Academies Press, Washington, DC.

Reed, L. 1995. Nutritional toxicology of tannins and related polyphenols in forage legumes. Journal of Animal Science 73:1516-1528.

Salmi, A. P.; Risso, I. A. M.; Guerra, J. G. M.; Urquiaga, S.; Araújo, A. P. and Abboud, A. C. S. 2013. Growth, nutrient accumulation and nitrogen fixation of Flemingia macrophylla. Revista Ceres 60:079-085.

Satter, L. D. and Slyter, L. L. 1974. Effect of ammonia concentration on rumen microbial protein production in vitro. British Journal Nutrition 32:199-208.

Sniffen C. J.; O'Connor J. D.; Van Soest P. J.; Fox, D. G. and Russel, J. B. 1992. A net carbohydrate and protein system for evaluating cattle diets: II. Carbohydrate and protein availability. Journal of Animal Science 70:3562-3577.

Taiz, L. and Zeiger, E. 2004. Fisiologia vegetal. 3th ed. Artmed, Porto Alegre.

Tiemann, T. T.; Lascano, E. C.; Wettstein, H. R.; Mayer, A. C.; Kreuzer, M. and Hess, H. D. 2008. Effect of the tropical tannin-rich shrub legumes Calliandra calothyrsus and Flemingia macrophylla on methane emission and nitrogen and energy balance in growing lambs. Animal 2:790-799.

Valente, T. N. P.; Lima, E. S.; Henriques, L. T.; Machado Neto, O. R.; Gomes, D. I.; Sampaio, C. B. and Costa, V. A. C. 2011. Anatomia de plantas forrageiras e a disponibilidade de nutrientes para ruminantes. Veterinária e Zootecnia 18:347-358.

Van Soest, P. J. 1994. Nutritional ecology of the ruminant. 2th ed. Cornell University Press, Ithaca. 
Van Soest, P. J.; Robertson, J. B. and Lewis, B. A. 1991. Symposium: carbohydrate methodology, metabolism, and nutritional implications in dairy cattle. Journal of Dairy Science 74:3583-3597.

Vieira, P. F. 1980. Efeito do formaldeido na proteção de proteínas e lipídeos em rações para ruminantes. Thesis (D. Sc.). Universidade Federal de Viçosa, Viçosa, MG.
Waterman P. G. and Mole, S. 1994. Analysis of plant phenolic metabolites. Blackwell Scientific Publications, London.

Whittenbury, R.; McDonald, P. and Bryan-Jones, D. J. A. 1967. Short review of some biochemical and microbiological aspects of silage. Journal of the Science of Food and Agriculture 18:441-444. 